\title{
NO HELP WANTED. MEDICAL RESEARCH EXCHANGE BETWEEN RUSSIA AND THE WEST DURING THE SECOND WORLD WAR
}

\author{
by
}

\section{E. H. BEARDSLEY*}

EVERYONE with some familiarity with the history of World War II is aware that relationships between the Soviet Union and her Western Allies were tenuous at best. On major issues, such as Russian aid requests and the launching of a second front, major disputes arose. Not as well known is the fact that that same discord also marked the lesser wartime relations. A case in point were the efforts of the U.S.A., Canada, and Great Britain to exchange valuable medical and health information with the Russians. Throughout the war, Moscow was not only unwilling to commit herself to any permanent system of sharing but was at times reluctant even to take from the West medical information and techniques she badly needed.

The story of Allied medical relations is equally instructive as to the state of AngloAmerican co-operation, which was clearly far from perfect. Where the Russians were concerned, America and Britain were often careless of each other's national interests and sensibilities, almost to the point of competing for Russia's favour. Each nation, but particularly the British, had a high opinion of its own creativity in medical research and was resentful of the other's seeming willingness to pass itself off to the Russians as the leader of medical science in the West.

Problems between Washington and London, of course, were minor ones and resulted mostly in annoyance. Difficulties with Russia, on the other hand, were more significant because they probably impeded the Soviets' ability to wage war. Had Moscow been less suspicious of her Western allies and more willing to accept medical help from the West-and it is likely that Britain and America could have benefited from more information from Russia-it was entirely possible that a larger number of Soviet soldiers and civilians could have survived the Russian War.

Almost immediately after the Nazi invasion of Russia in June 1941, Great Britain and the U.S. began efforts to set up a permanent medical exchange with the Soviet Union. Each country at that time had its own reasons for wanting a Russian connexion, but both were convinced of the military value of such exchange. Britain, who had stood alone against the Germans since the fall of France, was concerned to do everything she could to sustain Russian resistance. One problem the Soviets faced, which especially concerned British medical and military leaders, was the threat of typhus among Soviet soldiers and civilians. Although the Russians denied the danger and maintained that they had the situation under control, the British knew that was not so. Entomologist P. A. Buxton, an expert in the international health field, stated

*E. H. Beardsley, Ph.D., Associate Professor of History, The University of South Carolina, Columbia, South Carolina 29208, U.S.A. 


\section{E. H. Beardsley}

flatly that "epidemic typhus, spread by lice and no other way, is at this moment [October 1941] a grave threat to the populations of Eastern Europe and other places. An outbreak might not only cause a vast amount of disease and death but also dislocate the transport, supplies of food, and the whole of what is generally called the 'war effort'." Exchanging medical personnel with the Soviets, the British thought, would be an inoffensive way to get the Russians to accept the expert help they needed.

The Americans, who were not to enter the war until December 1941, had a less pressing interest in medical collaboration, but they were still eager to share Russia's findings in the field of military medicine. Aviation medicine was one area in which the Soviets had made large strides. John Fulton, Yale physiologist and assistant head of the Division of Medical Sciences of the National Research Council, admitted to being "much impressed by the material that has come out of Russia ... during the past four or five years. It must mean that they have much more unpublished. If we exchange information with them, I don't believe for a moment that it will be a oneway exchange ...".2

Acting on the premise that the Russians would be as interested in exchange as the West, London and Washington, jointly, in the summer of 1941 asked the Soviets if they would be willing to receive an Anglo-American mission, as a prelude to a systematic interchange, to discuss a broad range of medical and health topics. ${ }^{3}$ Three months later, the Russians replied. They had no objection, to exchange per se, but for the present the military situation was too critical to allow attention to anything else. England's ambassador to Russia, Archibald Clark-Kerr, added a warning that Whitehall should not consider sending the mission unilaterally because it "would not be welcome [to the] Soviet Government at present."4

For over a year the matter lay dormant. Then, in December 1942, the Soviets unexpectedly reopened the issue. Professor Sergei Yudin, a leading Russian surgeon, proposed to his friend, the British ambassador, that England and America each send three orthopaedic surgeons to the U.S.S.R. to observe Russian methods of treating battlefield fractures. The ambassador quickly relayed the invitation to London and offered to put the Americans in the picture, as well, by informing their embassy in Moscow. ${ }^{5}$

Although Yudin's proposal narrowed the scope of exchange considerably, British medical leaders responded eagerly, for a surgical mission would at least put Western scientists into Russia, and once there they could push for expanded interchange. ${ }^{6}$ Others outside the medical sphere were also interested. The previous September, Prime Minister Winston Churchill had persuaded the Russians to agree to a general

1 P. A. Buxton to D. T. Richardson, 3 October 1941, Papers of the War Office, WO 32/9797, Public Record Office, London (hereinafter, WO and PRO). On Buxton see Who's Who, London, A. \& C. Black, 1955, p. 436.

IJohn Fulton to A. V. Hill, 25 August 1941, file 3123, v. iii, Medical Research Council Papers, London (hereinafter, MRC); on Fulton see Who's Who in America, 24th ed., Chicago, Marquis Who's Who, 1946, p. 827.

- Fulton to Hill, 25 August 1941, f. 3123, v. iii, MRC.

- His Majesty's Ambassador (Kuibyshev) to Foreign Office, 17 November 1941, Memo 69, CAB 90/2, Papers of the Cabinet, PRO; also see Summary of Correspondence for 1941, WO 32/9797, PRO.

3. J. Growther to Sir Edward Mellanby, 17 December 1942, f. 3132/4, MRC.

- Mellanby to R. W. Watson-Jones, 31 December 1942, f. 3132/4, MRC. 


\section{No help wanted}

scientific and technical exchange, but thus far the Soviets had not upheld their end of the bargain. The Yudin proposal raised hopes in the Foreign Office that Moscow had decided to be more open. The surgical mission, in fact, might prove to be the catalyst of a freer flow of scientific information. ${ }^{7}$

Anyone who dealt with the Russians, though, quickly learned not to let his hopes climb too high and to expect frequent changes of the Soviet heart. The proposed surgical mission was a case in point. In early February 1943 Professor Yudin informed the British ambassador that London and not he must take the initiative for the mission. Then, a week later, Yudin dropped out of the picture altogether, and medical leaders in London began to see no "immediate prospect of a visit taking place."8

But with equal suddenness, there was another shift. In March, Soviet Foreign Secretary V. I. Molotov informed Ambassador Clark-Kerr that Russia would be happy to receive a surgical mission, although that time Moscow did not mention the Americans. Buoyed by the news of Russia's change of heart, the British moved speedily to get things ready.

The task of organizing the mission fell chiefly to Sir Edward Mellanby, Secretary of the Medical Research Council and chief medical adviser to the War Cabinet. Acquainted with the whims of Russian diplomacy, Mellanby was determined to avoid any delay which might give the Russians time to change their minds. ${ }^{9}$

The first task was to select personnel. Asking for a representative from each of the Services, Mellanby was satisfied with every nominee except the candidate from the Air Ministry, Air Commodore Stanford Cade. Cade's inclusion, Mellanby feared, would hold up the mission's departure, because as a naturalized British subject of Russian origin, he would be suspect in Moscow. As Mellanby explained, the Russians "are extremely touchy on ... . bringing people of Russian birth back to Russia at the present time and make a special point of finding out whether such people have ever had any relation to the White Russian Party." 10 The Air Ministry agreed to a replacement, and by mid-April the mission's departure seemed imminent.

Then, an unforeseen problem arose. Somehow the Americans had never learned of the Soviets' December offer nor of any of the later negotiations. Perhaps ClarkKerr or the Foreign Office had been at fault, or perhaps the British ambassador's original communiqué to American ambassador William Standley had been mislaid. But whatever the cause, it was only in April that Standley discovered the existence of an impending mission and informed the State Department of it. ${ }^{11}$

\footnotetext{
- On the scientific agreement between the U.S.S.R. and Britain, see E. H. Beardsley, 'Secrets between friends: applied science exchange between the Western Allies and the Soviet Union during World War II', Social Studies of Science, 1977, 17: 447-473; see also Brigadier Crew to Mellanby, c. 17 January 1943, f. 3132/4 MRC.

- Mellanby to Watson-Jones, 9 February 1943, f. 3132/4, MRC; also see HM Ambassador (Moscow) to Mellanby, 3 February 1943, f. 3132/4, MRC.

- Draft letter, Mellanby and Henry Dale to Royal Navy Medical Service Directors, 26 March 1943, f. 3132/4 MRC; A. H. Jones to Mellanby, 1 April 1943, f. 3132/4 MRC; on Mellanby, see Who's Who, London, A. \& C. Black, 1945, p. 1869.

10 Mellanby to Air Vice-Marshal Sir Harold Whittington, 13 April 1943, f. 3132/4, MRC; also Mellanby and Sir Henry H. Dale to RN Medical Service Directors, 26 March 1943, f. 3132/4, MRC.

11 American Embassy, Moscow, to Secretary of State, 11 April 1943, Committee on Medical Research, General Records, "Russia" file, Record Group 227, National Archives, Washington, D.C. (hereinafter, CMR, Gen Rec, “Russ", RG 227).
} 


\section{E. H. Beardsley}

Washington was caught completely by surprise. Diplomatic and medical leaders not only had known nothing of Britain's negotiations but also had been forming plans of their own, as the result of a separate inquiry from the Russians two months before. In February 1943 the Soviet Foreign Office had asked General Philip R. Faymonville, U.S. Lend-lease co-ordinator in Moscow, if the Americans could supply them with information on treatment of phosphorus burns and of wounds from the poisonous gases, Lewisite and Yperite. In addition, the Soviets inquired about American interest in sharing information on surgery, chemical defence, and epidemiology, but without mentioning the on/off surgical mission. ${ }^{12}$

Keenly interested in sharing Russia's vast experience in battlefield medicine and having just suffered a Russian rejection of a visit to Moscow by an American typhus commission, the Americans were jubilant over the report of Faymonville's conversation. During the next few weeks, members of the Committee on Medical Research (CMR), America's counterpart to the Medical Research Council, had been busy planning ways to capitalize on Russia's new-found spirit of co-operation. When news of the British surgical mission reached them, CMR chairman A. N. Richards and his colleagues, along with officials of the State Department, were just about to propose a general exchange of secret research information, to be coupled with the visit of an American expert. The projected mission was also to include representation from Canada and Great Britain. ${ }^{13}$ Obviously, those plans now had to wait.

In London Mellanby was equally surprised by the mixup, although at first there was some American unwillingness to believe it. The U.S. ambassador in London, John Winant, who had also just learned about the mission, believed that Mellanby had purposely kept the U.S. in the dark and called on him to tell him that and to insist on American representation. Mellanby responded rather huffily, that the ambassador's suspicions were totally misplaced, that he had said nothing to Winant earlier simply because he was sure the Americans had been informed. In any case, he said, it was not his "job to keep in touch with political and diplomatic circles."14

As for American representation, Mellanby told Winant that while he would normally welcome U.S. participation, he doubted whether there was time to arrange it in the present case. If the mission did not leave soon, Moscow would infer that the British were not serious and might cancel all visas. ${ }^{15}$ But when Winant promised to move swiftly, Mellanby relented.

Selecting an American delegation was no problem at all. General Paul R. Hawley, chief American surgeon in Europe, had two professors of surgery on his London staff, so he simply asked them to go. The two were Colonel Elliott Cutler, formerly professor of surgery at Harvard Medical School, and Lt. Colonel Loyal Davis, a neurosurgeon from Northwestern University, who was to represent the CMR. In

13 American Embassy, Moscow, to Secretary of State, 21 February 1943, CMR, Gen Rec, "Russ", RG 227.

1s On the development of mission plans see Edward R. Stettinius to Henry L. Stimson, 27 February 1943; Vanevar Bush to Edward R. Stettinius, 8 March 1943; Wilder Penfield to Stettinius, 11 March 1943; and Cordell Hull to Bush, 31 March 1943, all in CMR, Gen Rec, "Russ", RG 227. On the typhus mission see American Embassy, Moscow, to Secretary of State, 11 April 1943, CMR, Gen Rec, "Russ", RG 227.

14 Mellanby, Note on interview with U.S. ambassador Winant, 16 April 1943, f. 3132/4 MRC.

16 Ibid. 


\section{No help wanted}

May, Canadian neurosurgeon Wilder Penfield joined the list, representing his country's Medical Research Council. ${ }^{16}$ So by the time the mission finally departed in early July 1943 (delayed not by the Americans but by flight safety problems), it had grown into a tri-nation enterprise.

Hoping to exchange information on many topics beyond the field of surgery-on typhus, for example - the three governments were also determined to make the surgeons' visit the first step towards a permanent medical exchange with the Russians. To whet Moscow's interest in such an accord, the British were even prepared to share highly secret medical information with their Soviet allies. ${ }^{17}$

Not even a good offer, though, was always sufficient to win Russian backing, so when the group of surgeons arrived in Moscow, they were not sure what kind of reception awaited them. Their initial session with Soviet health and medical officials was encouraging. When British naval surgeon Gordon Gordon-Taylor suggested a tour of base and front-line hospitals, Commissar of Health Georgii Miterev readily agreed. When Gordon-Taylor asked, further, if Russian and Western doctors would be allowed to discuss research questions, his host again assured him that that would be arranged. The Americans concluded the happy session by presenting the Russians with two million units of penicillin, the first of the new antibiotic they had seen. ${ }^{18}$

But if the visit started well, relations between visitors and hosts soon deteriorated and finally collapsed completely. An omen of impending problems was the microphone that the American doctors discovered in the gilt trim of their hotel mirror. It also became clear that they would not be allowed to go anywhere or talk to anyone without their two "shadows", Professors Koreisha and Rufanov, the first a respected scientist but the latter merely a Communist Party hack. Morever, Russian medical scientists practically ignored their visitors. In meetings, Soviet surgeons neither asked questions nor answered them, and with the exception of Professor Yudin, none called at the mission's hotel headquarters. When Yudin visited, he came late at night and tapped on a table throughout the conversation to foil the bugging device. ${ }^{19}$

Clearly, Russian doctors were afraid to make contact, a result, in part, of their government's decision to limit discussion strictly to fractures. But their timidity was also rooted in the atmosphere of fear and suspicion that pervaded Russian science. As British delegate Ernest Rock Carling observed, "on many subjects there is an official opinion, and ... it is unwise for any Professor or Doctor to express a contrary

\footnotetext{
16 Ibid.; Gordon Gordon-Taylor, 'The Anglo-American-Canadian Surgical Mission to Russia, July, 1943', Br. J. Surg., 1944, 31: 205-207; on CMR involvement, see Richards to Dean Acheson 17 April 1943, CMR, Gen Rec. "Russ", RG 227; on Penfield, see Penfield to Sir Henry Dale, 8 May 1943, f. 3132/4, MRC.

17 On plans to broaden the mission, see MRC to C. R. Harrington, 28 April 1943, f. 3132/4, MRC; also 'Outline for basis of exchange of confidential medical information between the U.S.S.R. and the Research Councils of the U.S., Great Britain, and Canada,' 31 May 1943, f. 3132/4, MRC; on Britain's willingness to give away its secrets see W. L. Burnes to A. L. Thomson, 14 June 1943, f. 3132/4, MRC; on the flight delay see R. Watson-Jones, to Mellanby, c. 15 June 1943, f. 3132/4 MRC.

10 'Report of the initial meeting with U.S.S.R. public health, academic, and military medical officers', 5 July 1943, f. 3132/4, MRC.

10 Loyal Davis, 'Surgical mission to Russia', [n.d.], unpublished typescript in possession of the author; also see Davis, 'Neurological surgery', in Activities of surgical consultants, Washington, D.C., Office of the Surgeon General, Department of the Army, 1964, vol. 2, p. 426.
} 


\section{E. H. Beardsley}

view." 20

One official opinion, apparently, was that Soviet medicine was so effective that problems in the treatment and control of disease simply did not exist. Certainly, it was impossible to find an official who would admit the presence of any epidemic. Yet according to Westerners who had seen conditions first-hand, problems were legion. Major John F. Waldron, a U.S. Army Medical Corps doctor assigned to the staff of Faymonville, the Co-ordinator of Lend-Lease in Moscow, had served in Russia since 1941. Waldron's practice included the American diplomatic and military colony, as well as resident Englishmen, Frenchmen, and Poles, and his experiences up to the summer of 1943 suggested that health conditions were desperate. Typhus, according to Waldron, remained a major and unsolved problem; tularaemia was "epidemic along most of the front"; and malaria was "rampant from the Black Sea to the Arctic". Yet epidemics were only the beginning of Russia's problems. A case in point was nutrition. According to Waldron, "the lower classes are literally starving. Gross evidence of avitaminosis is seen everywhere."21

In view of such conditions, Moscow's prohibitions on open discussions made little sense to the Western surgeons, who soon began to wonder why the Russians had invited them in the first place. The best explanation they could find was that Moscow merely wanted to parade Russian surgical technique and to prove that communist medicine had caught up with that in the capitalist West. Vice-Commissar of Health Sergei Kolesnikov, for one, was eager to know what his visitors thought of Russian military surgery and questioned them at length about their views. Admittedly, Russia had lagged far behind the West in World War I, but in the last twenty-five years, he proclaimed, the Soviets had made great improvement. The Russians' continuous posturing and preening reminded American Loyal Davis of the antics of ten-year-old boys "who brag about the size of their houses and chimneys and recklessly claim that their fathers can lick anyone." 22

Only at the last session, on the eve of their departure, did the Westerners get the Russian scientists to lower their guard and engage in more open discussion. Taking advantage of the opening, they urged the Russians to consider joining the system of exchange which Canada, the U.S., and Britain had inaugurated and which included routine sharing of research reports and the maintenance by each country of medical liaison offices in the capitals of the others. Vice-Commissar Kolesnikov admitted privately that he was interested in sharing medical secrets without constant government censorship, and his view seemed to be that of other Soviet professionals. But if Russian doctors were eager for a liaison, Carling and the others knew that the

${ }^{20}$ Carling to J. F. A. Burke, 5 August 1943, N4481, FO 371/36929, PRO; also see Carling, 'Report of British-American surgical mission to the U.S.S.R.", 17 September 1943, f. 3132, MRC. On the narrow limits placed on the talks see Standley's interview with Molotov, in American Embassy, Moscow, to Secretary of State, 11 April 1943, CMR, Gen Rec, "Russ", RG 227. Molotov feared that broader discussions, especially on questions of epidemics, might cause panic among civilians.

"1 K. B. Turner, Conversation with Major John F. Waldron, 8 July 1943, CMR, Gen Rec, "Russ", RG 227.

" Carling, 'Second Interview with the People's Commissar (Public Health)', 3 August 1943, f. 3132/4, MRC; also Davis, 'Neurological surgery', op. cit., note 19 above, p. 439. Although the American and British delegates did not talk to Waldron (he was in Washington at the time of the mission), they did confer with others in the American colony in Moscow, who shared Waldron's concern. Thus, the visitors would most surely have been aware of existing conditions. 


\section{No help wanted}

"unknown factor is the government control", and that any Soviet participation in medical exchange depended on approval by higher authorities. ${ }^{23}$

The mood in London following the return of the mission was understandably gloomy, for the assessment was that the trip had been a failure. ${ }^{24}$ But in Washington quite another attitude prevailed. There, medical leaders and State Department officials chose to overlook the problems of the July mission and to concentrate instead on the more promising prospect of a broad-based research exchange, hinted at by the Russians in February 1942. The mission which failed, after all, had been a British venture, and there was no cause for American discouragement over that.

Actually, the Americans had never stopped preparing for the other mission. In mid-July, while Allied surgeons were still in Moscow, Harvard President James Conant, then serving as assistant head of the Office of Scientific Research and Development (the parent agency of the CMR), wrote to Mellanby and to his counterpart in Canada, C. J. MacKenzie, telling them of Russia's interest in exchanging information with the U.S. on a wide range of medical topics, including research. The U.S., Conant said, had decided to propose a visit to Moscow by an American expert, who would take with him information on ten important topics in the field of war medicine. Since the British and Canadians had contributed much of that information, Conant wanted to obtain their approval of the plan before Washington went further. In addition, Conant told Mellanby and MacKenzie that he would welcome British and Canadian participation in such a mission. ${ }^{25}$

The British reacted to Conant's proposal with both puzzlement and annoyance. A few days after Conant's letter reached London, Mellanby got the first gloomy reports of the July mission, and he was at a loss to understand how the Americans could take so rosy a view of a situation that the British perceived as an utter disaster. Misinterpreting Conant to say that the Russian overture to them came during the July visit, Mellanby and his associate, Carling, concluded that the Americans had simply read more into the friendly attitudes of Russian surgeons at the last Moscow meeting than was warranted. Agreeing that no proposal from Soviet doctors constituted a serious offer until it received approval from the Soviet government, Mellanby and Carling felt strongly that Washington should wait until the Russians responded to the exchange proposal that Carling, Davis, and Penfield had already made in July before taking any further initiatives. ${ }^{26}$

The Foreign Office viewed the American plans with outright annoyance. The July mission had been a joint enterprise, as well it should have been in view of the joint origin of Allied research, yet the U.S. was now trying to move off independently, and that did not impress Whitehall. C. E. Wilson of the Foreign Office spoke for his colleagues when he said that "it seems a pity that we should have to move forward

\footnotetext{
20 Interview between Davis, Penfield, and Carling and Vice-Commissar of Public Health, f. 3132/4, MRC.

24 Mellanby to Conant, 10 August 1943, f. 3132/4, MRC.

26 Conant to Mellanby, 14 July 1943, N3381, FO 371/36929, PRO. The subjects on which Conant wanted to inform the Russians were: (1) British anti-Lewisite; (2) penicillin; (3) typhus vaccine; (4) plasma proteins; (5) atabrine; (6) surgical infections, burns, shock; (7) insect repellents; (8) fungus infections; (9) prevention of infection by use of aerosols; (10) goggles.

20 Mellanby to Conant, 10 August 1943, f. 3132/4 MRC; Carling to Burke, 5 August 1943, N4481, FO371/36929, PRO.
} 


\section{E. H. Beardsley}

under the wing of the Americans."27 Not only that but the Russians, Whitehall felt, were "sour at the present time" and would not be receptive to any overture from the West. Urging a new project on them would not only be futile but would also hurt that mission's chances. ${ }^{28}$

In August, Mellanby, who fully shared the pique of the Foreign Office, replied to Conant. With admirable restraint, he told Conant that he was "surprised to know how successful you had been in developing your plans." While he had no reason to doubt that the American "scheme will be carried through," in view of the reports he had seen, he felt that the wisest course would be "to remain inactive for two months or so" before taking any other initiatives. ${ }^{29}$ Not hearing anything further from the Americans, Mellanby wrote again in September, that time to Vanevar Bush, Conant's boss in the Office of Scientific Research and Development, urging the same course and stressing that when another mission was proposed, it should be a joint enterprise..$^{30}$

While it was Mellanby's understanding that Bush had accepted his counsel, the Americans apparently received conflicting signals from the British. Sir John Anderson, Lord President of the Privy Council and thus Mellanby's superior, was in Washington in July and August, and Conant and Richards thought that they had won his approval of their plans. But when he returned to London and saw the reports of the mission, Anderson had second thoughts and agreed that the Americans should shelve their proposal until the foreign ministers' conference in October, when the Russians "might ... become sweeter". 31

The Americans, however, in their determination to push the mission forward, failed to discover, or chose to ignore, Anderson's change of heart, and in August they made their first overture to the Russians. In late October the latter, after two months of silence, accepted the proposal. Thus when Washington, a week later, suddenly announced to the British that it was sending an American medical research mission to Moscow as soon as possible, the British were caught totally off guard. More distressing was the news that the mission was to be entirely an American show. Bush assured Mellanby that the American ambassador had tried to get the Russians to accept British and Canadian representation but that the Soviets said that their invitation was for the Americans only, because "the Soviet Government had not been requested to receive representatives from these [other] countries."32

Bush's announcement set off an uproar in London. In the Foreign Office, the Americans were suddenly cast as villains. "It appears," said Foreign Office first

27 Wilson, Minute Sheet, 11 August 1943, N4481, FO 371/36929, PRO.

23 C. F. A. Warner to W. L. Gorell Barnes, 4 September 1943, N4738, FO 371/36929, PRO.

20 Mellanby to Conant, 10 August 1943, f. 3132/4, MRC. The Canadians, by contrast, urged the Americans to go ahead with their plans. See C. J. MacKenzie to Conant, 17 July 1943, CMR, Gen Rec, "Russ", RG 227.

* Mellanby to Bush, 29 September 1943, N5528, FO 371/36929, PRO.

:1 On Anderson and his views see Mellanby to Conant, 10 August 1943, f. 3132/4, MRC; A. N. Richards, Memo, 11 August 1943, CMR, Gen Rec, "Russ", RG 227; W. L. G. Barnes to A. R. Dew, 19 August 1943, N4481, FO 371/36929, PRO; Warner to Gorell Barnes, 4 September 1943, N4738, FO 371/36929, PRO.

as Bush to Mellanby, 7 November 1943, N6796, FO 371/36930, PRO. The first American proposal was made on 19 August. American Embassy to Secretary of State, CMR, Gen Rev. "Russ", RG 227. 


\section{No help wanted}

secretary A. R. Dew, who knew well both the Russians and Americans, "that the Americans have blandly ignored the proposal made in Sir Edward Mellanby's letter to Dr. Bush . . . and brushing aside the suggestion for a joint . . . approach have gone ahead with their own proposal ... . This is rather sharp practice."3s And not just sharp, but larcenous as well, Mellanby thought, for much of what the U.S. was planning to give the Russians had been discovered by British scientists.

Mellanby was probably angrier than anyone over the prospect of the Americans representing themselves in Moscow as the leaders of Western science, for in his mind British medical research was far superior to American. Sometimes British visitors to Washington had the temerity to rate U.S. research ahead of British efforts, and on those occasions Mellanby was quick to offer rebuke. In 1942, his own liaison officer sent home such a report, and Mellanby's response was swift and acid-edged. "I think", he wrote to J. H. Burn, Professor of Pharmacology at Oxford, that "it is important that you should return to England in the not too distant future, because it would help you to keep a balanced judgment as to the relative value of some of the work that is going on in the two countries." 34

More troublesome to London than American bad manners and presumptiousness, though, was the likelihood that if U.S. scientists went to Russia alone and were successful in setting up a permanent medical exchange, which was after all their main objective, the British would not be included. That would be totally unacceptable to London, for it would not only put the two Western nations on an unequal footing with a common ally, but also deny the British the Moscow contact they felt they must have to open an information flow into and out of the U.S.S.R. ${ }^{35}$ Mellanby voiced a common sentiment when he insisted that Britain must "put up some kind of side against America . ...". ${ }^{36}$ Accordingly, Whitehall instructed the British ambassador in Moscow to tell the Soviets that Britain expected to be included in any medical mission, for her representatives had, after all, joined in the proposal for an expanded exchange the previous July. ${ }^{37}$

Although the British were convinced that the U.S. was trying to steal a march on them, simple misunderstanding, coupled with American impatience, were more likely explanations for Washington's handling of the matter. Bush's justification for hurrying the mission was that the information they wanted to give to Russia, information they had offered nearly three months before, would not have much military value if they held on to it any longer. Certainly, Bush, Conant, and their colleagues in the CMR had no objection to the British joining the mission, if they could get ready in time. ${ }^{38}$

A. R. Dew, Minute Sheet, 12 November 1943, N6796, FO 371/36930, PRO. On Dew see Who's

Who, London, A. \& C. Black, 1945, p. 731.

24 Mellanby to Burn, 2 December 1942, f. 3151/2, MRC.

25 On the Allies' interest in having resident medical representatives in Moscow, see Carling to C. F. A. Warner, 4 December 1943, N7230, FO 371/36930, PRO.

* Mellanby to Burke, 29 November 1943, N7118, FO 371/36930, PRO; Clement Attlee to Anthony Eden, 10 November 1943, N6796, FO 371/36930, PRO.

27 Ibid.

26 Bush to Mellanby, 7 November 1943, N6796, FO 371/36930, PRO. There was possibly more to the matter than Bush admitted at the time. He said later that it was neither war needs, nor interest in out-distancing the British which underlay the mission, but rather Bush's concern about the balance of power in the post-war period. According to the Office of Scientific Research and Development 


\section{E. H. Beardsley}

The British had every intention of doing so, and the first step was to get Moscow's approval. In December the Russians signalled their willingness to include the British, so all that remained was for them to select their personnel and obtain visas. ${ }^{39}$ The two men whom Mellanby most wanted to send were Howard Florey and E. B. Chain, the Oxford scientists who had proven the clinical value of penicillin. ${ }^{00}$ Surely, Florey and Chain could put up a "side against America" if anyone could.

But right away there were difficulties. Chain's name, the Foreign Office believed, had to be withdrawn because he, like Cade before him, was a naturalized British subject. Ernst Boris Chain was born in Germany, and his father, Michael, had been of Russian origin; these circumstances might make him unwelcome in Moscow. Whitehall tried to secure the approval of a substitute, Dr. A. Gordon Sanders, the distinguished bacteriologist from the Pathological Institute, University of Oxford, to help Florey demonstrate the use of penicillin against burns and wounds. However, the Russians replied that they could only grant one visa. Florey, who was already dissatisfied about Chain's rejection, said that in that case he would not go.41

Meantime, the American delegation, comprised of A. Baird Hastings, a Harvard physiologist and CMR member, and Michael Shimkin of the National Cancer Institute, an American of Russian birth, had arrived in London and was soon pressing to be off to Moscow, with or without the British. Hastings and Shimkin promised not to discuss penicillin until Florey arrived, but the British did not see how that would be possible. The two delegations must go to Moscow together. ${ }^{22}$

Despite London's efforts, that was not to be. The Americans left London on 17 December 1943. Florey and the now approved Sanders, though delayed in London because of visa problems, did catch the Americans in Teheran. But then Florey became ill with influenza, and he and Sanders had to stay behind for nearly a week while Hastings and Shimkin proceeded alone to Moscow. ${ }^{43}$

As it turned out, that delay caused no problems, for arrangements in Moscow took several additional days and gave the British time to arrive. Once discussions did begin, in January, it was immediately apparent that the 1944 mission was to be far more successful than the surgeons' visit the summer before. The Russians were not only more open to general discussions but also more willing to share their research

director, he proposed the mission to divert President Roosevelt from a plan to send Moscow some highly secret weapons information, a disclosure Bush regarded as a foolish give-away of American power. See Bush, Pieces of the action, New York, William Morrow, 1970, p. 140.

*o Minute Sheet, 1 December 1943, N7118, FO 371/36930, PRO. Canada was not interested in accompanying the second mission but wanted to be a part of any exchange arrangement.

- Mellanby to Burke, 29 November 1943, N7118, FO 371/36930, PRO. In 1945 Florey and Chain shared the Nobel Prize in physiology or medicine with Alexander Fleming. Nobel Lectures, Physiology or Medicine, 1942-1962, Amsterdam, Elsevier, 1964, pp. 96-145.

1 On Chain see Minute Sheet, 1 December 1943, N7118, FO 371/36930, PRO, and FO to Moscow, c. 11 December 1943, N7184, FO 371/36930, PRO; on the other problems see ibid. and FO to Moscow, 3 December 1943, N7118, FO 371/36930, PRO.

¿2 Ibid. For some reason the Russians did not make an issue of Shimkin's origin. Perhaps they did not know of if, or perhaps it was simply predictable Russian unpredictability. It was also possible, of course, that the British exaggerated Moscow's sensitivity on the issue.

aO to Moscow, 17 December 1943, N7184, FO 371/36930, PRO; Florey to G. W. Wilson, 22 December 1943, N7638, FO 371/36930, PRO; Teheran to FO, 29 December 1944, N7725, FO 371/36930, PRO. Problems in Teheran were noted in A. Baird Hastings to the author, 9 August 1977 and in Michael Shimkin to the author, 23 August 1977. 


\section{No help wanted}

and military medical experience. The latter information Britain and America particularly coveted just then because of the impending European invasion, which would confront the West with massive battlefield casualties for the first time. Perhaps the Russians' new attitude was attributable merely to the whims of Soviet diplomacy. Or, perhaps it sprang from the fact that by late 1943 the German invasion had begun to crumble: with their survival no longer in doubt, the Soviets could finally begin looking to the future and to ways that the West might help them contend with accumulated problems in such areas as medicine and public health.4 But whatever the reason, it was apparent to observers like Averill Harriman, the new American ambassador in Moscow, that "the Soviets agreed to open up before the arrival of Doctors Hastings and Shimkin and they did so with increasing frankness during the course of their visit in Moscow."45

In terms of winning its major aim, an ongoing medical exchange, the mission was much less successful. While the Russians professed an interest in future sharing of information, they were not willing to permit exchange on Soviet soil. If it were to occur, it would have to take place in Washington and London, where representatives of the Russian Red Cross and Red Crescent Societies would act as conduits of information. In answer to British objections that such a plan would prevent any dialogue between working scientists, the Soviets responded that they did not contemplate personal discussions of research, only the exchange of written reports.

Actually, the British knew what the Russians were going to propose shortly before the mission left London, for Peoples' Commissar of Health Georgii Miterev (in response to the July, 1943 proposal!) had informed the MRC that secrets exchanged would have to take place without a "special bureau" in Moscow. ${ }^{46}$ Mellanby had hoped that once in Russia American and British scientists could convince the Soviets to change their minds. But Miterev remained adamant, and as far as the British were concerned, hopes for a real medical exchange were fruitless. ${ }^{47}$ Foreign Office counsellor C. F. A. Warner reflected the general frustration when he observed that "the Soviet authorities are clearly at their old game of keeping us aloof." 48 Britain had sought long and hard for a viable sharing arrangement with Moscow, but all they had gained was Miterev's "one-sided arrangement".40

The Americans, incorrigible optimists when it came to Russia, took a different view. They regarded Miterev's position as one that would surely yield to the right amount of patience and goodwill, and in fact Hastings and Shimkin believed they were on the threshold of a significant breakthrough as a result of the Moscow

a The U.S. and British interest in sharing Russia's battlefield experience is reflected in Richards' Memo, 11 August 1943, CMR, Gen Rec, "Russ", RG 227; as an example of Russian eagerness to share Western medical information about this time see V. V. Lebedenko to Kermit Roosevelt, jr., 16 September 1943, CMR, Gen Rec, "Russ", RG 227.

“s Harriman's views are included in Confidential Memo, 19 February 1944, CMR, Gen Rec, "Russ", RG 227.

* Carling to Warner, 4 December 1943, N7230, FO 371/36930, PRO.

" See Mellanby to Lord President of the Privy Council, 27 January 1944, N644, FO 371/43342; also Minute Sheet, 19 January 1944, N424, FO 371/43342; on the defects of Russia's proposal see E. M. Wilson, 5 February 1944, N644, FO 371/43342. All are in the PRO.

4 C. F. A. Warner, 8 February 1944, N644, FO 371/43342, PRO. On Warner see Who's Who, London, A. \& C. Black, 1945 p. 2842.

- Minute Sheet, 19 January 1944, N424, FO 371/43342, PRO. 


\section{E. H. Beardsley}

meetings. To exploit that possibility Hastings, with Harriman's concurrence, cabled the State Department from Moscow that it should immediately invite Vasilii Parin, Vice-Commissar of Public Health, to the U.S. on a return mission. In addition, the CMR should make plans to send a top American scientist to Moscow for several months. Until such a representative arrived, Hastings urged that Commander F. R. Lang, a physician assigned to the U.S. Military Mission in Moscow, be named as CMR agent to keep in touch with Russian research and to act as the medium of exchange between the two countries. ${ }^{50}$

For a while there were signs that Hastings' approach might pay off. Lang did gain access to some Russian laboratories and sent a number of reports to Washington, until he returned to the U.S. in the summer of 1944. In addition, nine Soviet scientists came to the U.S. on brief visits that year to inspect work in progress at various research facilities like the Mayo Clinic. But Parin, whose visit was to signal the beginning of a regular and permanent exchange, never came. The Russians kept delaying his departure until, in November 1944, they postponed it indefinitely. With no-one having been named to replace Lang in Moscow, routine interchange had stopped the previous summer. ${ }^{51}$

Hastings and his colleagues in the CMR, however, were not willing to let the matter rest. Convinced of the military value of medical exchange and looking now to the post-war period, when international collaboration in medicine would, it was hoped, serve the cause of peace, Hastings, Richards, and Bush determined to try to revive Soviet-American exchange, again by sending experts to the U.S.S.R. ${ }^{52}$

Accordingly, in the early months of 1945 the CMR made a careful search for the right men. By early April a mission was ready, and that time its constitution would be exclusively American, the British apparently having decided to end what they regarded as a futile Russian courtship. U.S. participants included old hand Michael Shimkin, University of Minnesota surgeon Owen Wangensteen, and Harvard physiologist Eugene Landis. If admitted to the Soviet Union, they were prepared to give an up-to-date report on topics covered the previous year, plus information on matters such as blood preservation, clinical uses of antimalarial drugs, and the effects of decompression and anoxia. Besides information exchange, the mission was prepared to stay in Russia for several months to provide continuous liaison. On 17 April Bush cabled Harriman the details, asking him to seek permission for the mission's entry, but giving him leeway to modify it as he thought best. ${ }^{53}$

On 5 May, following assurances from Bush that the Russians had honoured most of the previous year's promises in the matter of exchange, Harriman forwarded the American proposal to the Soviet Foreign Office. A month later the Russians told Harriman that it was under consideration. After that, Moscow was silent. Near the

${ }^{50}$ The contents of Hastings' cable of 6 February are in Bush to Franklin S. Cooper, 8 February 1944, CMR, Gen Rec, "Russ", RG 227.

s1 A. B. Hastings to Richards, 19 January 1945, CMR, Gen Rec, "Russ", RG 227; also see D. C. Balfour to Richards, 7 March 1945, CMR, Gen Rec, "Russ", RG 227. On Parin's visit see Norman T. Kirk to Richards, 18 April 1944 and Hastings to Bush, 3 November 1944, both in CMR, Gen Rec, "Russ", RG 227.

s2 Richards to H. S. Diehl, 18 March 1945, CMR, Gen Rec, "Russ", RG 227. In the same file see Bush to Thomas Parin, 21 March, 1945, and Hastings to Richards, 19 January 1945.

sa 'Memo on second mission to Russia', [n.d.], CMR, Gen Rec, "Russ", RG 227. 


\section{No help wanted}

war's end, the American scientists who had been holding themselves ready to go to Russia "at a moment's notice" were simply told that the "interchange had been called off, and without explanation". ${ }^{54}$

Thus ended the long and largely futile search for co-operation from the Russian ally in the exchange of medical information. Efforts, of course, had not been entirely fruitless. But what exchange there was flowed largely in one direction only, from West to East. In the West, continuous sharing on a face to face basis was taken for granted as the most efficient method of putting information to work for the Allied cause. But in Russia, ideals of openness, generous giving, and free inquiry were alien notions, and the Soviets preferred to reject the aid of Western medicine if the price of that help was the presence in the U.S.S.R. of Westerners themselves.

That rejection, though, came at the price of increased Russian suffering and loss of life. Edward Mellanby was one who observed the cost of the Soviet obsession for isolation. Commenting at the time of the 1944 mission on the great value of the information then being given to the Russians, Mellanby noted that much of it "could have been sent to Russia months or even years ago," if the Russian medical delegate had accepted the Medical Research Council's invitation in 1942 to "sit in on its meetings and read its reports." ${ }^{55}$ But he did not, and the cost was surely high.

\section{SUMMARY}

Throughout World War II Britain and the U.S., in an effort to strengthen the Eastern Front, attempted to bring the Soviet Union within their system of medical research exchange. Except for a brief period in 1944, however, Western leaders found the Soviets unwilling to participate in any on-going interchange, even though Russian civilians faced severe health problems throughout the war which could have been ameliorated by such sharing of information.

The basis of the Soviet objection was the West's desire to establish a permanent liaison office in Moscow, to provide continuing research exchange. Not only did the Russians not want foreign scientists permanently residing on Soviet soil, but they refused even to discuss whole areas of medicine and health, like the question of typhus (which was reportedly out of control in parts of Russia).

Despite the many Russian rebuffs, the U.S. and Britain continued to try for an exchange agreement. In 1943 and again in 1944 Allied medical missions actually went to Moscow, and at the end of the war the U.S. was trying unsuccessfully to send a third. In their eagerness to bring the Soviets into a sharing arrangement, U.S. and British scientists often worked at cross purposes and in competition with one another, which produced much ill feeling.

The story of wartime medical research exchange is instructive in its relevation of underlying tensions within the Anglo-American alliance and in its depiction of a Soviet ally which preferred to risk the health of its own soldiers and civilians rather than open its doors to onlookers from the West.

st Owen H. Wangensteen to the author, 26 July 1977. On American Embassy (Moscow) handling of the proposal see George Kennan to Secretary of State, 23 April 1945; Bush to Harriman, 3 May 1945; Kennan to Secretary of State, 10 May 1945; and Harriman to secretary of State, 8 June 1945, all in CMR, Gen Rec, "Russia-Proposed Second Russian Mission" file, RG 227.

w Mellanby to Lord President of the Privy Council, 27 January 1944, N644, FO 371/43342, PRO. 